DOI: $10.31866 / 2410-1915.20 .2019 .172430$

УДК 008:316.7

\title{
КУЛЬТУРНИЙ ПРОСТІР, КОМУНІКАЦІЯ, МІСТО: СПІВВІДНОШЕННЯ ПОНЯТЬ
}

\section{Олійник Оксана Миколаївна}

Викладач, ORCID:0000-0002-4687-2408,oksana_oliinyk@ukr.net, Київський національний університет культури і мистецзвв, вул. Є. Коновальця, 36, Київ, Україна, 01133

Мета статті - визначити смислове наповнення та співвідношення понять «культурний простір», «комунікація», «місто». Методологія дослідження грунтується на загальнонаукових методах (аналізу, синтезу, узагальнення) з опорою на спеціальні методи, інтегровані з низки соціогуманітарних наук - соціології, культурології, філософії, комунікативістики тощо. Наукова новизна полягає у визначенні співвідношення понять «місто», «культура», «комунікація», «культурний простір» для обгрунтування розуміння сучасного міста як культурно - комунікативного простору. Висновки. Місто - це середовище, основною ознакою якого є простір, що характеризується спільною діяльністю людей на матеріальному, фізичному та духовному рівнях, у результаті якої створюються певні феномени (міська ідентичність, міський спосіб життя, міська забудова, міська мода та ін.), які існують та транслюються за посередництва культурних символів та комунікативних матриць, які покликані задовольняти потреби, що виникають у результаті інтеракції, а також забезпечувати їі дієвий результат.

Ключові слова: культурний простір; культура; комунікація; інтеракція; місто; культурно-комунікативний простір.

\section{Вступ}

Будь-яке сучасне місто - це, насамперед, відповідне культурне і комунікативне середовище існування людини, тому дослідження міста в культурології, насамперед, повинно спиратися на з'ясування характеристик цих понять, синергія яких у сучасних умовах інформаційного суспільства та бурхливого розвитку комунікаційних технологій проявляється дедалі більше. Усе вищезазначене актуалізує дослідження як культурно-комунікативний простір 3 першочерговим визначенням смислового наповнення кожної зі складових цього поняття у співвідношенні з низкою найбільш затребуваних у плані аналізу характеристик.

Поняття «простір культури», «культурний простір», «комунікація», «місто» давно перебувають у колі наукового зацікавлення дослідників. Найбільш грунтовні розробки міста як простору вийшли з-під пера американського географа і урбаніста Е. Соджі (у деяких перекладах Е. Сойї -

(c) Олійник О. М., 2019 
від E.W.Soja): «Третій простір: Подорожі до Лос-Анджелеса та інших реальних і уявних місць», «Як писати про місто з точки зору простору», «Постмодерна географія: відновлення простору в критичній соціальній теорії», «Постмодернізм: Критичні дослідження міст і регіонів» та ін.

Серед західних дослідників найбільше зацікавлення викликають класичні праці теоретиків постструктуралізму, як-то: П. Бурдьє «Соціальний простір: поля і практики», «Соціологія соціального простору», Е. Гідденса «Конституювання суспільства: нарис теорії структурації», а також відомого теоретика інформаційного суспільства М. Кастельса, зокрема «Реконструкція соціального смислу в просторі потоків» та ін. Крім того, серед філософів-постмодерністів культурний простір цікавить М. Фуко, Ж. Дельоза, М. Гайдеггера, Ж. Бодрійяра та ін.

Низка досліджень вийшла 3-під пера вчених пострадянського простору: А. Кулєшова «Культурний простір як сукупність габітусів», І. Свирида «Простір і культура: аспекти вивчення», А. Бистрова «Культурний простір як предмет філософської рефлексії», В. Гатальський «Культурно-освітній простір як соціально-педагогічна система», О. Гуткін, О. Листвіна, Г. Петрова, О. Семенищєва «Феномен культурного простору», В. Тишков «Культурний смисл простору», К. Політковська «Культурний простір у сучасній науці» та ін.

Поняття культурного простору зустрічається і в законодавстві нашої країни, зокрема в Законі України «Про культуру»: «Культурний простір України - сфера, в якій відповідно до законодавства провадиться культурна діяльність та задовольняються культурні, інформаційні та дозвіллєві потреби громадян, що охоплює, зокрема, радіо і телебачення, періодичні друковані видання та книговидавничу продукцію, ринок культурних благ, а також культурно-мистецьке середовище» (Закон України «Про культуру», 2010).

Що стосується української науки, то дослідження культурного простору сьогодні ще не стали предметом пильної уваги. Найбільш грунтовною працею є докторська дисертація О. Степанової «Національний культурний простір України: концептуальні засади розвитку і становлення». Культурний простір також згадується у низці статей: А. Філіна «Культурний простір: основні його види та культурна діяльність суспільства щодо задоволення соціокультурних потреб громадян», М. Собуцький «Мовна ситуація і мовно - культурний простір західноєвропейського середньовіччя». Тобто, ця тема є досить новою для української культурології, а відтак ще більш актуальною.

\section{Мета статті}

Мета статті - визначити смислове наповнення та співвідношення понять «культурний простір», «комунікація», «місто». 


\section{Виклад матеріалу дослідження}

Відтак спробуємо збагнути взаємозв'язок понять «простір», «комунікація», «культура», «місто» та визначити основні методологічні позиції, в межах яких їх розглядають дослідники.

Поняття культурного простору вже давно ввійшло в науковий лексикон. Загалом культурно-комунікативний простір - це проблема міждисциплінарного характеру, хоча всіх дослідників об'єднують почасти спільні методи і теоретичні конструкції, які лише дещо по-новому концептуалізуються в різних наукових підходах. Водночас його часто трактують у теоріях комунікації, і навпаки - описують комунікацію відповідно до структури культурного простору, позаяк сама культура $\epsilon$ наслідком інтеракції людей, які спільно розбудовують і покращують умови свого існування у межах відповідних територіально-просторових кордонів. Тим паче, що сьогодні вже ні в кого не викликає заперечень висловлена ще в середині XX ст. думка засновника структурної антропології К.Леві-Строса, що у соціальних науках відбудеться «коперникова революція», відповідно до якої суспільство в цілому буде інтерпретуватися через використання теорії комунікації (Lévi-Strauss, 1958, с. 95). Так, постнекласична інформаційна парадигма особливу увагу надає мережевій логіці сучасного соціуму, відповідно до якої суспільство розуміється як мережа комунікацій, що створюють можливості для самоопису суспільства і його самовідтворення (Кривокора, 2007).

М. Каган взагалі $\epsilon$ прихильником комунікативного підходу до розуміння простору, зокрема культурного. Міжсуб'єктна взаємодія, на його думку, - це справжній механізм формування культури, що може актуалізуватися в діахронному аспекті - в соціокультурному часі і в синхронному аспекті - соціокультурному просторі, що включає різні зв’язки особистостей, поколінь, культур (Каган, 1989).

П. Бурдьє розглядає культурний простір як певну структуру взаємин між людьми, як «ансамбль невидимих зв'язків, які формують простір позицій, зовнішніх один до одного» (Бурдье, 1994, с. 18).

Автор теорії мозаїчної культури А. Моль характеризує культурний простір як протяжність, в якій поширюється і функціонує культурна інформація, і виокремлює в ньому кілька рівнів: 1) «пам'ять світу»- вся інформація, накопичена людством протягом історії; 2) культура колективу, соціальної групи, суспільства; 3) культура індивіда. Отже, у концепції А. Моля культурний простір - це комунікативний процес, в якому забезпечено передачу знань від колективного рівня до індивідуального (Моль, 1973, с. 72-83).

Загалом культурний простір - це складний динамічний багатофункціональний часово-просторовий континуум, основною структурною і системоформуючого складника якого є діяльність людини на матеріальному, фізичному та духовному рівнях. Тому це не абстрактна категорія, а життєвий простір існування людини, наповнений, окрім матеріальних, i артефактами ментально-психічного характеру, які викликають певні емоційні переживання та відчуття. 
У культурології культурний простір розглядається як одна з форм побутування і втілення культури як складної динамічної система, яка постійно змінюється, оскільки, з одного боку, вона сама виробляє нові цінності, знаки і символи, а з іншого - наповнюється, взаємозбагачується надбаннями інших культур. I як би не належав до процесу акультурації, він $є$ безкінечним і невідворотнім, оскільки втримує в собі споконвічне прагнення до оновлення, яке водночас не передбачає відкидання старого, а відтак - бережливе ставлення до спадщини.

При цьому, володіючи неповторною архітектонікою і специфічним динамізмом, на який суттєво впливає час, кожна культура володіє власними засобами трансляції, які надають процесам комунікування власні імпульси до змін. Водночас будь-який простір передбачає комунікацію або всередині або за його межами - як конкретного ареалу проживання людей. Чим більш відкритим є культурний простір, тим більше він стимулює до розширення культурних контактів, реального діалогу та полілогу культур.

Зрозуміло, що особливості культурного простору залежать від географічного розташування, природного середовища, рельєфу, ландшафту, ресурсів, розмірів, віддаленості або близькості до водних шляхів сполучення тощо, що значно полегшує або ускладнює існування людини, зумовлюючи специфічні способи комунікування, організації побуту, системи господарювання тощо.

Культурологія взагалі вже давно цікавиться проблемами комунікації, позаяк будь-яку трансляцію культурних цінностей можна розуміти як обмін/передачу матеріальних і духовних артефактів від покоління до покоління або у процесі спілкування людей, або у процесі міжкультурної взаємодії за допомогою мови та інших знакових систем, що власне і призводить до формування культури та її неповторного ландшафту в часовому i просторовому вимірах. Культура взагалі щонайкраще слугує для відображення того розмаїття зв'язків і відносин, які існують у суспільстві, а відтак сама є формою - наслідком комунікації, в якій взаємодія людей у процесі діяльності не тільки призводить до творення нових матеріальних чи духовних цінностей, а й за рахунок взаємовпливів призводить до змін на особистісному рівні. Усе це дає підстави вважати культуру наслідком інтеракції - як спільної діяльності індивідів.

До смислового наповнення культури належать i знаки, які мають матеріальне вираження, як-то: слово, річ, малюнок, текст та ін., які, володіючи певним змістом, слугують розумінню культури як такої. Різноманітність знаків i знакових систем зумовлена пізнавальною діяльністю людини, необхідністю фіксувати отримані знання і передавати ïx наступним поколінням. Тобто культура - це велика інформаційна знаково-символічна система, яка за допомогою спеціальних програм диктує певну модель поведінки людині, формуючи при цьому своєрідні закони суспільства, а також створює нові художні твори. Відомі знакові системи, існуючі в культурі, у підсумку і створюють «культурний простір», який відрізняється від матеріально-фізичного і має свої закони існування, власне буття (Политковская, 2018). 
Л. Петров у праці «Масова комунікація і культура. Вступ у теорію та історію» описує чотири види комунікації: матеріальна (транспортна, енергетична, міграція населення, епідемії та ін.); генетична (біологічна, видова); психічна (внутрішньо-особистісна, автокомунікація); соціальна. Останні три типи є смисловими, тобто в якості переданого повідомлення виступає не дана у відчуттях річ або речова властивість, а смисл, який досягається в результаті розумової діяльності, осмислення. При цьому дотримується такий закон комунікації: повідомлення смислових комунікацій завжди мають ідеальний (духовний) зміст i, зазвичай, але не завжди - матеріальну, чуттєво сприйняту форму. Важливо звернути увагу на те, що всі види смислових комунікації взаємопов'язані через особистість (людину), тобто суб’єкта соціальної комунікації (Петров, 1999).

Будь-яке місто має свою структуру, комунікативну систему і способи комунікації, яку по-різному інтерпретують теоретичні положення представників різних шкіл і концепцій. Водночас у їх розуміннях $є$ низка спільних тверджень, які проектуються у методологічну площину нашого дослідження міського простору. Так, на думку дослідника А.Урсула, комунікація - це обмін інформацією між складними динамічними системами і їх частинами, які в змозі приймати інформацію, накопичувати i перетворювати іï̈ (Урсул, 2010). К. Черрі трактує комунікації як соціальне об'єднання індивідів, що здійснюється за допомогою мови чи знаків, встановлення загальнозначущих наборів правил для різної цілеспрямованої діяльності (Черри, 1972).

М. Каган розмежовує поняття комунікації і спілкування. На його думку, комунікація - це один з різновидів діяльності людства, який забезпечує єдність між індивідами, що спілкуються. «Спілкування має і практичний, матеріальний, і духовний, інформаційний, і практично-духовний характер, а комунікація - це суто інформаційний процес передачі повідомлень (Каган, 1988, с. 143-146).

Загалом ключовим, на нашу думку, у визначенні комунікації є іï розуміння як засобу передачі інформації між різними частинами системи та системами як такими, а також як засіб інтеракції між людьми в умовах життєдіяльності за посередництва низки матеріальних і духовно смислових компонентів.

У межах феноменологічної методології, Ю. Хабермас розуміє міжособистісні інтеракції як інструмент реалізації практичних інтересів людей, як спосіб емансипації, вивільнення від економічних, політичних та інших впливів, що спотворюють комунікації і відіграють латентну роль примусу. У своїй теорії комунікативної дії він протиставив цілераціональну та комунікативну поведінку людини (Хабермас, 2001).

Крім того, позаяк інтеракція передбачає цілеспрямовану діяльність, вона повинна володіти низкою якостей, які уможливлюють вирішувати безліч практичних завдань для формування життєвого простору. Тобто більшість дослідників фактично розуміють комунікацію як взаємодію (інтеракцію), яка полегшує спільну діяльність людей, а відтак, на думку Т. Шибутані, є обміном, який забезпечує кооперативну взаємодопомогу, 
уможливлюючи координацію дій великої складності (Lévi-Strauss, 1958, c. 126).

Суголосною є позиція американського соціолога У.Шрамма, який зазначає, що саме прогрес у розвитку системи комунікації $є$ основним рушійним чинником розвитку людської цивілізації (Schramm, 1971). Що власне і спостерігається у будь-якому місті, яке виникало як результат стихійної самоорганізації людей для забезпечення, насамперед, базових потреб, зокрема потреби в безпеці. Місто - динамічна система, яка самоорганізується, а тому почасти важко піддається управлінському впливу.

Як будь-яке середовище існування людини, місто ввібрало, трансформувало і самостійно виробило низку особливих феноменів, які існують та транслюються за посередництва культурних символів та комунікативних матриць, формуючи відповідний культурно-комунікативний простір, який водночас багато дослідників визначає як міська культура. Культурний простір міста як певна цілісна форма, як власне і сама культура, володіє iii ж особливостями, які, на думку А.Флієра, відображають зміст, сенс і соціальний досвід, які складаються у певному просторі і часі (Флиер, 2000 , с. 31). Також розуміння культури випливає 3 комунікативнознакового (смислового) змісту співжиття у конкретному соціумі. Тобто кожна культурна форма, з одного боку, сповнюється специфічними смислами (цінностями, знаннями, нормами тощо), 3 якими пов’язана діяльність людей у ній, а з іншого - задовольняє їх потреби у цих смислах.

\section{Висновки}

Отже, місто - це культурно-комунікативне середовище, основною ознакою якого $є$ простір, який характеризується спільною діяльністю людей, у результаті якої створюються певні феномени, які, покликані задовольняти потреби, які виникають в результаті інтеракції, а також забезпечувати іï реалізацію. Це складна система взаємопов'язаних феноменів, серед яких міська ідентичність, міський спосіб життя, міська забудова, міська мода та ін. Останнє дає змогу рефлексувати їх відповідно до низки інших смислових компонентів, які, можливо, нині не здобули ще наукової концептуалізації як специфічні явища міського простору, як, наприклад, зовнішня реклама, міський сленг, міська мода тощо, однак це не применшує їх значення у формуванні неповторного рельєфу міста та $€$ перспективним напрямом подальших досліджень.

\section{Список використаних джерел}

1. Бурдье П. Начала. Москва : Socio-Logos : Адапт, 1994. 287 с.

2. Закон України Про культуру: за станом на 18 груд. 2014 р. Верхов. Рада України. Київ : Парлам. вид-во, 2014. 22 с.

3. Каган М. С. К вопросу о понимании культуры. Философские науки. 1989. № 5 . C. $78-81$. 
4. Каган М. С. Мир общения: проблема межсубъективных отношений. Москва : Политиздат, 1988. 315 с.

5. Кривокора Е. И. Системные основания исследования организационных коммуникаций. Проблемы современной экономики. № 1(21). 2007. URL: http:// www.m-economy.ru/art.php?nArtId=1238. (дата обращения: 12.03. 2019).

6. Моль А. Социодинамика культуры. 3-е изд. Москва : Изд-во ЛКИ, 2007. 404 с.

7. Петров Л.В. Массовая коммуникация и культура: ведение в теорию и историю. Санкт-Петербург: Санкт-Петербург. гос. ун-т. 1999. 211 с.

8. Политковская К. В. Культурное пространство в современной науке. Вестник Санкт-Петербургского государственного института культуры. 2018. Вип. 1(34). С. 25-29.

9. Урсул А. Д. Природа информации. Философский очерк. Челябинск : Челябинская гос. акад. культуры и искусств, 2010. 231 с.

10. Флиер А. Я. Культурология для культурологов. Москва : Академический проект, 2000. 496 с.

11. Хабермас Ю. Моральное сознание и коммуникативное действие. Пер. с нем. Санкт-Петербург : Наука, 2001. 380 с.

12. Черри К. Человек и информация: пер. с англ. Москва : Связь,1972. 367 с.

13. Шибутани Т. Социальная психология. Пер. с англ. В. Б. Ольшанского. Ростов на Дону : Феникс, 1999. 544 с.

14. Lévi-Strauss C. Structural Anthropology. New York : Inc. Publishers, 1958. 410 p.

15. Schramm W. The Nature of Communications Between Humans. The Process and Effects of Mass Communication. Urbana : University of Illinois Press, 1971. PP. 3-516.

\section{References}

Burd'e, P. (1994). Nachala [Beginnings]. Moscow: Socio-Logos: Adapt.

Cherri, K. (1972). Chelovek i informatsiya [Person and Information]. Translation from English by Kuli V.I. and Fridman V.Ya. Moscow: Svyaz'.

Flier, A.Ya. (2000). Kul'turologiya dlya kul'turologov [Culturology for cultural studies]. Moscow: Academic project.

Kagan, M.S. (1989). K voprosu o ponimanii kul'tury [On the issue of culture understanding]. Filosofskie nauki, no. 5, pp.78-81.

Kagan, M.S. (1988). Mir obshcheniya: problema mezhsub'ektivnykh otnoshenii [The world of communication: the problem of intersubjective relationships]. Moscow: Politizdat.

Khabermas, Yu. (2001). Moral'noe soznanie $i$ kommunikativnoe deistvie [Ethic Consciousness and Communicative Action]. Translation from german. St. Petersburg: The science.

Krivokora, E.I. (2007) Sistemnye osnovaniya issledovaniya organizatsionnyh kommunikatsii [System bases for the study of organizational communications], Problemy sovremennoi ekonomiki, no.1(21). Available at:http://www.m-economy.ru/art.php?nArtId=1238 [Accessed: 11 March 2016]

Lévi-Strauss, C. (1958). Structural Anthropology. New York: Inc. Publishers.

Mol', A. (2007). Sotsiodinamika kultury [Socio-dynamics of culture]. Moscow: Leningrad Shipbuilding Institute. 
Petrov, L.V.(1999). Massovaya kommunikatsiya $i$ kul'tura: vedenie v teoriyu i istoriyu [Mass Communication and Culture: Introduction to Theory and History]. St. Petersburg: St. Petersburg State University.

Politkovskaya, K.V. (2018). Kul'turnoe prostranstvo v sovremennoi nauke [Cultural space in modern science]. Vestnik Sankt-Peterburgskogo gosudarstvennogo instituta kul'tury, issue 1(34), pp. 25-29.

Ursul, A.D. (2010). Priroda informatsii. Filosofskii ocherk [The nature of information. Philosophical essay]. Chelyabinsk: Chelyabinskaya gosudarstvennaya akademiya kul'tury i iskusstv.

Schramm, W. (1971). The Nature of Communications Between Humans. The Process and Effects of Mass Communication. Urbana: University of Illinois Press, pp. 3-516.

Shibutani, T. (1999). Sotsial'naya psikhologiya [Social Psychology]. Translation from English V. B. Olshansky. Rostov-on-Don: Feniks.

Zakon Ukrainy Pro kulturu [Law of Ukraine on Culture]. (2014). Verkhovna Rada Ukrainy. Kyiv: Parlamentske vydavnytstvo.

\section{CULTURAL ENVIRONMENT, COMMUNICATION, AND CITY: RELATIONSHIPS BETWEEN CONCEPTS}

\section{Oksana Oliinyk}

\section{Lecturer,}

ORCID:0000-0002-4687-2408,oksana_oliinyk@ukr.net,

Kyiv National University of Culture and Arts,

Kyiv, Ukraine

The aim of the article is to determine the semantic content and the relationships between concepts "cultural space", "communication", and "city". The methodology of the research is based on general scientific methods as analysis, synthesis, and generalization, backed by special methods, integrated with a number of socio-humanities sciences: sociology, culturology, philosophy, communication studies, etc. Scientific novelty consists in an attempt to determine the relationships between the concepts of "city", "culture", "communication", "cultural environment" to justify the understanding of the modern city as a cultural and communicative space. Conclusions. The city is an environment, the main feature of which is the space characterized by people overall activity at the material, physical and spiritual levels. This activity creates certain phenomena (urban identity, urban lifestyle, urban development, urban fashion, etc.) that exist and are transmitted through cultural symbols and communicative matrices, which, in turn, are designed to meet the needs arising because of interaction and to ensure its effective result.

Keywords: cultural environment; culture; communication; interaction; city; cultural and communicative space. 


\section{КУЛЬТУРНОЕ ПРОСТРАНСТВО, КОММУНИКАЦИЯ, ГОРОД: СООТНОШЕНИЕ ПОНЯТИЙ}

\section{Олейник Оксана Николаевна}

Преподаватель, ORCID:0000-0002-4687-2408,oksana_oliinyk@ukr.net, Киевский национальный университет культуры и искусств, Киев, Украина

Цель статьи - определить смысловое наполнение и соотношение понятий «культурное пространство», «коммуникация», «город». Методология исследования основана на общенаучных методах (анализа, синтеза, обобщения) с опорой на специальные методы, интегрированные и ряда социогуманитарных наук социологии, культурологии, философии, коммуникативистики и т.д. Научная новизна заключается в определении соотношения понятий «город», «культура», «коммуникация», «культурное пространство» для обоснования понимания современного города как культурно-коммуникативного пространства. Выводы. Город - это среда, основным признаком которой является пространство, характеризующееся общей деятельностью людей на материальном, физическом и духовном уровнях, в результате которой создаются определенные феномены (городская идентичность, городской образ жизни, городская застройка, городская мода и проч.), которые существуют и транслируются при посредничестве культурных символов и коммуникативных матриц, которые, в свою очередь, призваны удовлетворять потребности, которые возникают в результате интеракции, а также обеспечивать ее действенный результат.

Ключевые слова: культурное пространство; культура; коммуникация; интеракция; город; культурно-коммуникативное пространство. 